\title{
Implementation of Accounting Technology and Financial Reporting Quality of Quoted Epos it Money Banks in Nigeria
}

\author{
Oladejo, M.O ${ }^{1}$, Yinus, S.O ${ }^{2 *}$, Aina-David, O.A ${ }^{3}$ \\ ${ }^{I}$ Department of Management and Accounting, LadokeAkintola University of Technology Ogbomoso, Oyo State, \\ Nigeria. \\ ${ }^{2}$ Department of Accounting, LadokeAkintola University of Technology Ogbomoso, Open and Distance Unit. Oyo \\ State, Nigeria \\ ${ }^{3}$ Department of Business Administration and Management, Moshood Abiola Polytechnic Abeokuta, Ogun State, \\ Nigeria
}

*Corresponding Author: Yinus, S.O, Department of Accounting, LadokeAkintola University of Technology Ogbomoso, Open and Distance Unit. Oyo State, Nigeria

\begin{abstract}
Accounting technology combines the study and practice of accounting with the design, implementation, and monitoring of information systems. Such systems use modern information technology resources in conjunction with traditional accounting controls and methods to provide users with the information necessary to manage the organization. Studies in this regard focusing on Nigeria bank were few and worthy of exploration. In line to this, the study evaluate the factors influencing the implementation of accounting technology practice and it alteration on the basic accounting procedure in the selected deposit money banks in Nigeria. Primary data were employed. Ten deposit money banks in Nigeria were purposively selected for the study. Three hundred copies of a questionnaire were administered randomly on the selected staff of the 10 deposit money banks sampled out of which two hundred and sixty were returned and used for the study. Data collected were analysed using descriptive statistics. Result revealed that all considered variables; Bank Size (BS), Cost of ICT Deployment (CID), Perceived Ease of Use (PEOU) and Perceived Benefit $(P B)$ influenced accounting technology implementation and that accounting technology practice has not altered the basic accounting procedure but rather improved the timeliness of report generation. . In view of the above findings it is recommended that Nigeria Banks should create more awareness to group users of financial information on the benefits entails to accounting technology usage.
\end{abstract}

Keywords: Financial Information, Users Confidence, Accounting Technology, Accounting Procedure, Nigerian Deposits Money Bank

\section{INTRODUCTION}

Evidence from the literature reveal that the usefulness of accounting data is the idea to improve value relevance of accounting information in the financial report. Accounting information systems are considered the backbone of information systems in the banks, as they summarize the events and operations that occurred in the bank and provide rational and reasonable results necessary for effective decision making (Akande, 2011).Accounting information system (AIS) is useful in all types of organizations especially the banking industry where the survival and growth of such organization depend to a large extent, on supplying effective accounting information to internal and external users (Khalid, 2004).More so ,financial reports are the building blocks of valuation and investment decisions been the formal records of business economic activities. The purpose of accounting information is to provide decision makers like investors, creditors, and managers with information to support their decisions (Ahmad, 2011). Literature revealed that financial information stated in financial statements is an avenue for the corporate firm to communicate their internal and external users on financial position the firm, financial information should be presented completely and free from error (Sulaimon, 2011).

Furthermore, literature shows that financial accounting information acts as a control mechanism for monitoring organization operational activities through their financial disclosure.The widespread failure in the financial information quality has created the need to improve the financial information 
quality. The influence of accounting technology on value relevance of published financial statement of Nigeria corporate organization, most especial banking sector has not been well explored. Howaccounting technologycan serve as an instrument of value relevance in term of reporting quality in the Nigeria banking sector need to be examined.

\subsection{Research Hypotheses}

$\mathbf{H O}_{1}$ : Accounting technology does not alter the basic accounting procedure in the selected deposit money banks in Nigeria

\section{CONCEPTUAL FRAMEWORK}

\subsection{Financial Information System}

Financial information is considered as the best media of communication between the company and various stakeholders of the company who assist them in evaluating and knowing the performance of organizations (Carol, 2002).The decision of investors is said to be qualitative and informed when published accounting information is of high quality.

Furthermore, the association between some accounting information and a change in share prices thus only exists if information conveyed by the accounting system is both reliable and relevant to the market. This inter alia allows testing for the incremental usefulness of some specific accounting information, the information content of accounting information published under specific accounting regimes (Veith and Werner, 2010).

\subsection{Basic Accounting Procedures and Regulation}

An accounting system tracks and controls the income and expenses of a business. Accounting systems can be as simple as a pen and notepad, and can be as complex as an international accounting staff of thousands utilizing the latest technological advancements. Based on accounting ethics following a set of basic accounting principles can be an effective way to gain experience in handling financial accounts. This include

a) Collecting Financial Documents

Financial records are vital in any accounting system. Small and large businesses alike should put systems in place to ensure that all income and expenses are recorded in some way, physically, electronically or both. Important financial documents include cash register tapes, invoices, incoming bills, salaries records, tax forms, and travel receipts. Financial documents can originate from a diverse range of locations and employees. Put a system in place to ensure that these documents make their way to a central accounting department in a timely manner.

b) Posting Transactions

Traditionally, accountants used financial documents to manually enter transactions into the various accounts in the company's accounting system. While this is still true to a certain extent, a large number of businesses have taken advantage of technological solutions to automatically post transactions. Proprietary automatic ordering software, for example, can be set up to automatically adjust the accounts in the accounting system via the company network. In this case, accountants use financial documents to verify accounting records and investigate any discrepancies.

c) Account Reconciliation

Checking your accounts against external records should be a regular activity in an accounting department. Checking internal records of company assets against bank account and investment portfolio statements can alert your accounting team to any differences between the two, as can checking your accounts payable records with your suppliers' records.

d) Accounts Payable and Receivable

Accounts payable consists of all money owed by your company to its suppliers and lenders. Accounts receivable is the exact opposite and consists of all money owed to you by customers and other debtors. A thorough accounting system involves systems of tracking the due dates and statuses of accounts payable and receivable and can even be set up to automatically pay bills on time or send notifications to delinquent account holders. 


\section{e) Internal and External Reporting}

Creating reports for management, investors and other company stakeholders is a vital function of an accounting system. Internal reports aid managers in decision-making by presenting operational data in a strategically relevant manner, allowing them to spot trends and areas of potential improvement. Publicly traded corporations are required to submit a range of financial reports to federal authorities throughout the year, including the annual report. Even privately held companies, however, may find themselves required to create reports for external stakeholders, such as lenders and private investors.

El-Gazzar, Finn and Tang (2009) illustrates the effect of regulation through an empirical study, especially in the airline industry. The emergence of the airline industry from regulation to nonregulation market structure provides a unique opportunity to test the value relevance of accounting information. El-Gazzar et al (2009) examines the value relevance of earnings and nonearning (book values) information and shows statistical evidence indicating that security prices are higher aligned with nonearning measurements in regulated markets than in deregulated markets. This can be explained by the high competitiveness in deregulated markets.

\subsection{Importance of Accounting Technology Practice}

Accounting technology practice are important to businesses in various ways. The use of computers is time-saving for businesses and all financial information for the business is well organized (Baren, 2010).

\section{- Time and Cost Savings}

Using electronic accounting Systems saves companies time and money. The use of a computer makes inputting accounting information simple. Transactions are entered into the system and the system processes and posts transactions accordingly. Electronic accounting Systems reduce staff time preparing accounts and reduce audit expenses as records are neat, up-to-date and accurate. Better use is made of resources and time; cash flow should improve through better debt collection and inventory control. More importantly, the system helps present financial reports on time to aid in the economic decision-making process of external users.

\section{- Organisation and Accuracy}

Electronic accounting Systems enables businesses to stay organized. When information is entered into the system, it makes finding the information easy. Employees can look up any financial information whenever it is needed. There is less room for errors as only one accounting entry is needed for each transaction rather than two (or three) for a manual system. The accounting records are automatically updated and so account balances (e.g. customer accounts) will always be up-to-date.

\section{- Storage and Speed}

Storing information is vital to a business. After information is entered into the system, theinformation is stored indefinitely. Companies perform backups on the system regularly toavoid losing any information. The introduction of electronic Accounting Systems provides the ability to see the realtime state of the company's financial position.

\section{- Distribution}

Electronic Accounting Systems allow companies to distribute financial information easily. Financial statements are printed directly from the system and are distributed internally and externally to those needing the information. Reports can be produced which will help management monitor and control the business, for example, the aged debtor's analysis will show which customer accounts are overdue, trial balance, trading and profit, and loss account and balance sheet. In effect, electronic Accounting Systems enable financial statements to be prepared and presented to meet the relevance and faithful representation criteria of financial statements.

\subsection{Factors Affecting Electronic Accounting Adoption/Implementation}

Evidence from past studies (Tilahunm, 2019; Ghasemi, Shafeiepour, Aslani and Barvayeh, 2011; Oladejo, 2014) have stated that adoption of an accounting information system can be determined by a number of independent or explanatory variables like chief executive officer innovativeness, 
management commitment, and perceived ease of use, human resource and perceived complexity of accounting information system, benefit of the system, level of risk attached to the system and machinery cost.

Human Resource Human resources are most likely to be core sources of continuous competitive advantage of organizations. Based on the studies Tilahunm (2019) there is a positive relationship between human resource and adoption of accounting information system in the hospitals of Jordan. Another study has found that the quality of accounting personals is an important factor in the adoption and implementation of an accounting information system. There is a significant correlation between human resource and intention to adopt computerized accounting information system Lack of skilled personnel is the main problem for small businesses not to adopt information technology in Canada (Thong, 1999). Tilahunm (2019) was of opined that management commitment improves the effectiveness of information system implementation because they provide the resources needed for information system developments.

\subsection{Financial Reporting Quality}

A financial report is a means of portraying financial accountability, in order for an organization to review the financial activities of the past year and make plans for the future. Evidence from the literature shows that timeliness is an important characteristic of quality financial information. To benefit users, financial information must be presented at the right time otherwise it loses relevance. Relevance is also a characteristic of the quality of financial reports. (Beest, Braam, andBoelens, 2009). financial information is relevant if it is capable of making a difference in decisions made by helping users to form predictions about the outcomes of the past, present, and future events either to confirm or correct prior expectations, it was also stressing that users must be able to compare the financial statements of the enterprise over time in order to identify trends in its financial position and performance. According to Pallai (2007) Understandability as a quality of financial reporting that enables users to perceive the significance of financial information. He argues that users are assumed to have a reasonable knowledge of business and willingness to study and understand the information. According to the International Accounting Standard Board (IASB), the essential principle of assessing the financial reporting quality is related to the faithfulnessofthe objectives and quality of disclosed information in a company's financial reports. All these are seen as qualitative characteristics which enhance the facilitation of assessing the usefulness of financial reports and also lead to a high level of quality.

\subsection{Empirical Review}

Akesinro and Adetoso (2016) investigate the effect of a computerized accounting system on the performance of banks in Nigeria. Using survey design of three selected banks (GTbank, Wema Bank and First Bank plc) in Nigeria. Findings show that computer accounting system has increased patronage of banks customers. Olaonapo and Odetayo (2015) examined the effect of accounting information system on organizational effectiveness with special reference to selected construction firms in the Ibadan metropolis. Specifically, the study examined the effects of accounting information on the quality of financial reports and decision making. Purposive sampling technique was adopted in selecting a total of ten personnel from each of the selected companies as a sample for the study. The results show that accounting information system has an effect on organizational effectiveness. Raed(2017) examine the impact of accounting information systems on the Banks Success 112 structure questionnaire distributed to the head offices of thesurveyed banks in Jordan and analysis through Correlation and multiple regression.Findings showed that accounting information systems have significant effects on banks success. Dandago and Rufai (2014) assessed Information Technology and Accountinginformationsystem in the Nigerian banking industry,both primary and secondary data wereused and Analysis of Variance (ANOVA) was used to test the hypothesis. The judgmental samplingmethod was used to obtain a representative sample population of selected deposit money bank through NSE book Fact.Finding a show that accountinginformation technology is relevant in simplifying issues and in the provision of quality informationin the Nigerian banking industry.

The construct of this study embedded on Technology Acceptance Model (TAM) because is one of the most influential models widely used in the studies of the determinant of technology acceptance. An individual may adopt a technology if he or she perceives it as convenient, useful and socially desirable even though they do not enjoy using the technology (Saga and Zmud, 1994). More so, Quality of 
financial information is seen as a means to determine the value relevance of accounting information to the end users. The study will embrace these theories to expound the influence of technology accounting practice on financial report quality and value relevance of accounting information to the end user of the financial report through consideration of appropriate, timely and accurate accounting information in order to make a decision on investment.

\section{Methodology}

Primary data were employed. Ten deposit money banks in Nigeria were purposively selected for the study. Three hundred copies of a questionnaire were administered randomly on the selected staff of the 10 deposit money banks sampled out of which two hundred and sixty were returned and used for the study. Data collected were analysed using descriptive and inferential statistics. Descriptive statistics was used to examine the implementation of accounting technologyand its alteration on basic accounting procedures toward user's confidence on financial information published by the Nigeria selected deposit money banks.

\section{RESULTS AND DISCUSSION}

\subsection{Socio Economic Characteristic of the Respondents}

Table 4.1 shows the socioeconomic characteristic of the sampled respondents. It discloses that $32.31 \%$ of respondents were male and $67.69 \%$ were females. Similarly, the table shows that $23.08 \%$ of the respondents are within the age bracket of fewer than 25 years, $54.62 \%$ of the respondents are within the age bracket of 26-40 years, while $22.31 \%$ are within the age of 41 years and above. $53.08 \%$ of the respondent is married, $41.54 \%$ are single, and $4.23 \%$ are divorcee while $1.15 \%$ is a widow. The result implies that $70 \%$ of the sampled selected banks staff are female and most of them are within the age bracket of 26-40years and married. The table also shows the education level of the sampled respondents, which reveal that above half $(52.31 \%)$ of the respondent are B.sc holder, $29.23 \%$ of respondents are NCE/OND/HND holder, while $18.46 \%$ of the sampled respondents hold seconddegree master. The result implies that most (Above half 52.31\%) staff of the sampled selected banks are degree holders. In table 4.1, the descriptive employment status of the respondent shows that $6.92 \%$ of the respondents are senior managers, $28.46 \%$ of the respondents are Accountant, $42.31 \%$ of the respondents are Marketers, and $11.54 \%$ of the respondents are Customer relation service while $10.77 \%$ of the respondents are a cashier. The result implies that all relevant units of the selected bank were sampled and were presented.

Table4.1. Frequency and mean score of Socio-Economic Characteristic of Respondents

\begin{tabular}{|c|c|c|}
\hline Variable & Frequency & Percentage \\
\hline $\begin{array}{l}\text { Sex: } \\
\text { Male } \\
\text { Female } \\
\text { Mean- } \mathbf{1 . 6 7 6 9 2 3}\end{array}$ & $\begin{array}{l}84 \\
\underline{176} \\
\underline{260} \\
\end{array}$ & $\begin{array}{l}29.60 \\
70.40 \\
100.00\end{array}$ \\
\hline $\begin{array}{l}\text { Age: } \\
\text { Less than } 25 \\
26-40 \\
41 \text { yrs Above } \\
\text { Mean- } \mathbf{1 . 9 9 2 3 0 8}\end{array}$ & $\begin{array}{l}60 \\
142 \\
\frac{58}{260}\end{array}$ & $\begin{array}{l}23.08 \\
54.62 \\
23.31 \\
100.00\end{array}$ \\
\hline $\begin{array}{l}\text { Marital Status: } \\
\text { Married } \\
\text { Single } \\
\text { Divorced } \\
\text { Widowed } \\
\text { Mean: } 1.534615\end{array}$ & $\begin{array}{l}138 \\
108 \\
11 \\
\underline{3} \\
\underline{260} \\
\end{array}$ & $\begin{array}{l}53.08 \\
41.54 \\
4.23 \\
\underline{1.15} \\
100 \%\end{array}$ \\
\hline $\begin{array}{l}\text { Educational background: } \\
\text { NCE/OND } \\
\text { BSC } \\
\text { Msc/MBA } \\
\text { Mean:1.892308 }\end{array}$ & $\begin{array}{l}76 \\
136 \\
\frac{48}{260} \\
\end{array}$ & $\begin{array}{l}29.23 \\
52.31 \\
\underline{18.46} \\
100 \% \\
\end{array}$ \\
\hline
\end{tabular}


Implementation of Accounting Technology and Financial Reporting Quality of Quoted Epos it Money Banks in Nigeria

\begin{tabular}{|l|l|l|}
\hline Position Held: & & \\
Senior manager & 18 & 6.92 \\
Accountant & 74 & 28.46 \\
Marketer & 110 & 42.31 \\
Customer care & 30 & 11.54 \\
Cashier & $\underline{28}$ & $\underline{10.77}$ \\
Mean-2.926923 & 260 & 100.00 \\
\hline Job Experience : & 70 & 26.92 \\
Less than 5yrs & 158 & 60.77 \\
6-10 & 31 & 11.92 \\
$11-14$ & $\underline{1}$ & $\underline{0.38}$ \\
15 and Above & 260 & 100.00 \\
Mean- 1.926923 &
\end{tabular}

Source: Author's Computation, (2019).

Perception on Factor influencing adoption of Accounting Technology in the selected sampled deposit money banks of Nigeria.

Table 4.2 shows the analysis of factor influencing Accounting technology adoption in the selected sampled deposit money banks of Nigeria as elicited from bank workers. The result shows that $(92.30 \%)$ of the stakeholder of financial Activities such as bank workers opined that Bank size has a high influence on Accounting technology adoption. Also, (69.23\%) of the respondent is also of the opinion that the Cost of ICT Deployment is also one of the major factors affecting adoption of the Accounting technology system by the deposit money banks of Nigeria. (73.50\%) of the stakeholders opined that Perceived Ease of Use (PEU) is part of factor influencing adoption of Accounting technology in the Nigeria deposit money banks. The results overview revealed that $(85.66 \%)$ of the respondent believed that the perceived benefit of Accounting Technology practiceis the major determinant for adoption in the Nigeria deposit money banks. This result supports the argument of (Patel and Connolly 2015; Oladejo, 2014) that opined perceived benefits, Perceived Ease of Use were main factors encouraging adoption of new technology.

Table4.2. Factor Influencing Accounting Technology adoption in the selected deposit money banks

\begin{tabular}{|l|l|l|l|l|l|}
\hline Influencing Factors & Very High & High & Undecided & Low & No Influence \\
\hline Bank Size (BS) & $\begin{array}{l}195 \\
(75 \%)\end{array}$ & $\begin{array}{l}45 \\
(17.30 \%)\end{array}$ & $\begin{array}{l}- \\
-\end{array}$ & $\begin{array}{l}8 \\
(3.08 \%)\end{array}$ & $\begin{array}{l}12 \\
(4.62 \%)\end{array}$ \\
\hline $\begin{array}{l}\text { Cost of ICT } \\
\text { Deployment (CID) }\end{array}$ & $\begin{array}{l}170 \\
(65.38 \%)\end{array}$ & $\begin{array}{l}10 \\
(3.85 \%)\end{array}$ & $\begin{array}{l}80 \\
(30.77 \%)\end{array}$ & - & - \\
\hline $\begin{array}{l}\text { Perceived Ease of } \\
\text { Use (PEU) }\end{array}$ & $\begin{array}{l}136 \\
(52.41 \%)\end{array}$ & $\begin{array}{l}57 \\
(21.09 \%)\end{array}$ & - & $\begin{array}{l}67 \\
(26.50 \%)\end{array}$ & - \\
\hline $\begin{array}{l}\text { Perceived Benefit } \\
\text { (PB) }\end{array}$ & $\begin{array}{l}200 \\
(78.51 \%)\end{array}$ & $\begin{array}{l}26 \\
(7.15 \%)\end{array}$ & $\begin{array}{l}10 \\
(3.05 \%)\end{array}$ & $\begin{array}{l}10 \\
(3.05 \%)\end{array}$ & $\begin{array}{l}14 \\
(5.18 \%)\end{array}$ \\
\hline
\end{tabular}

Source: Author's Computation, (2019).

Analysis of Stakeholders perception on Accounting Technology practice alteration of the basic accounting procedure in the selected Deposit Money banks of Nigeria

Analysis from Table 4.3 results on stakeholder's perception of financial report ofselected Deposit Money banks in Nigeria reveals that majority of the respondents $(76.92 \%)$ of the total respondents agreed; $(13.46 \%)$ of them disagreed while $(9.62 \%)$ of the respondent are undecided on the fact that accounting technology usage does not alter basic accounting procedure of recording by debit on the left hand side and credit on the right hand side. Hence these shows that electronic accounting usage does not alter basic accounting procedure of recording accounting transaction. Similarly, the table indicates that a large number of respondents, $(75 \%)$ of the respondents agreed that Accounting Technology system concerned with balancing of debit side to credit side, $(9.62 \%)$ of them disagreed, while $(15.38 \%)$ undecided. Hence these show that accounting technology system concerned with accurate balancing of accounting transaction as part of accounting procedures. More so, Analysis on table 4.4 shows that majority of respondents $(74.86 \%)$ of the respondents agreed that use of electronic accounting have error detect feature of double entry procedure, (15.77\%) disagreed while (5.77) were 
undecided. Hence the results show that the use of electronic accounting have error detect feature of double entry as part of basic accounting technology procedure. Furthermore, $(75 \%)$ of the respondent agreed that the use of Accounting integrate real and nominal account as double entry recording system does, $(8.62 \%)$ disagreed while $(15.38 \%)$ were undecided.

The results in Table 4.3 also reveal that majority of the stakeholder was of opinion that there is a significant relationship between accounting technology and Financial reporting quality of the Nigeria money deposit banks at (73.08\%). Similarly, respondents disagreed with the opinion that the use of accounting technologyaltered the basic accounting activities in the banking sector at (86.70\%). Hence the results reveal that use of accounting technology system has not Altered the basic accounting procedure in the banking sector, rather than improving the timeliness of report generation at $(75 \%)$ opinion of the selected sample stakeholder in Nigeria Deposit Money banks. Based on the result the null hypothesis is accepted. Showing that accounting technology practices has not altered the basic accounting procedure in the selected deposit money banks in Nigeria.

Table4.3. Analysis of Stakeholders perception on accounting technology practice alteration of the basic accounting procedure in the selected Deposit Money banks of Nigeria

\begin{tabular}{|l|l|l|l|l|l|l|}
\hline RESPONSES & SA & A & D & SD & U & TOTAL \\
\hline $\begin{array}{l}\text { Electronic accounting usage does not alter } \\
\text { basic accounting procedure of recording the } \\
\text { debit on the left hand side and credit on the } \\
\text { right hand side }\end{array}$ & $\begin{array}{l}145 \\
(55.77)\end{array}$ & $\begin{array}{l}55 \\
(21.15)\end{array}$ & $\begin{array}{l}20 \\
(7.69)\end{array}$ & $\begin{array}{l}14 \\
(5.77)\end{array}$ & $\begin{array}{l}26 \\
(9.62)\end{array}$ & $\begin{array}{l}260 \\
(100)\end{array}$ \\
\hline $\begin{array}{l}\text { Accounting Technology system concerned } \\
\text { with balancing of debit side to credit side. }\end{array}$ & $\begin{array}{l}86 \\
(33.08)\end{array}$ & $\begin{array}{l}109 \\
(41.92)\end{array}$ & $\begin{array}{l}8 \\
(3.08)\end{array}$ & $\begin{array}{l}17 \\
(6.54)\end{array}$ & $\begin{array}{l}40 \\
(15.38)\end{array}$ & $\begin{array}{l}260 \\
(100)\end{array}$ \\
\hline $\begin{array}{l}\text { Use of Electronic Accounting has error detect } \\
\text { feature of double entry procedure. }\end{array}$ & $\begin{array}{l}76 \\
(29.23)\end{array}$ & $\begin{array}{l}128 \\
(49.23)\end{array}$ & $\begin{array}{l}25 \\
(9.62)\end{array}$ & $\begin{array}{l}16 \\
(6.15)\end{array}$ & $\begin{array}{l}15 \\
(5.77)\end{array}$ & $\begin{array}{l}260 \\
(100)\end{array}$ \\
\hline $\begin{array}{l}\text { The use of Electronic Accounting integrates } \\
\text { real and nominal account as double entry } \\
\text { recording system does. }\end{array}$ & $\begin{array}{l}86 \\
(33.08)\end{array}$ & $\begin{array}{l}109 \\
(41.92)\end{array}$ & $\begin{array}{l}5 \\
(1.93)\end{array}$ & $\begin{array}{l}20 \\
(7.69)\end{array}$ & $\begin{array}{l}40 \\
(15.38)\end{array}$ & $\begin{array}{l}260 \\
(100)\end{array}$ \\
\hline $\begin{array}{l}\text { There is a significant relationship between } \\
\text { Electronic Accounting System and Financial } \\
\text { reporting quality of the Nigeria money deposit } \\
\text { banks }\end{array}$ & $\begin{array}{l}128 \\
(49.23)\end{array}$ & $\begin{array}{l}62 \\
(23.85)\end{array}$ & $\begin{array}{l}18 \\
(6.92)\end{array}$ & $\begin{array}{l}(6.15) \\
16\end{array}$ & $\begin{array}{l}36 \\
(13.85)\end{array}$ & $\begin{array}{l}260 \\
(100)\end{array}$ \\
\hline $\begin{array}{l}\text { Use of Electronic Accounting System Altered } \\
\text { the basic accounting activities in the banking } \\
\text { sector? }\end{array}$ & $\begin{array}{l}13 \\
(5.00)\end{array}$ & $\begin{array}{l}12 \\
(4.62)\end{array}$ & $\begin{array}{l}(65.38) \\
(70\end{array}$ & $\begin{array}{l}(21.92) \\
(3.08)\end{array}$ & $\begin{array}{l}\text { 260 } \\
(100)\end{array}$ \\
\hline $\begin{array}{l}\text { Use of Electronic Accounting System helps to } \\
\text { improve the timeliness of report generation } \\
\text { and quality of a report }\end{array}$ & $\begin{array}{l}95 \\
(36.54)\end{array}$ & $\begin{array}{l}100 \\
(38.46)\end{array}$ & $\begin{array}{l}10 \\
(3.85)\end{array}$ & $\begin{array}{l}23 \\
(8.85)\end{array}$ & $\begin{array}{l}32 \\
(12.30)\end{array}$ & $\begin{array}{l}125 \\
(100)\end{array}$ \\
\hline
\end{tabular}

Source: Author's Computation, (2019).

\section{CONCLUSION AND RECOMMENDATION}

The study concluded that all considered variables; Bank Size (BS), Cost of ICT Deployment (CID), Perceived Ease of Use (PEOU) and Perceived Benefit (PB) influencedAccounting technology adoption and that accounting technology practice has not altered the basic accounting procedure but rather improved the timeliness of report generation which enhance the value relevance of financial information published by the Nigeria deposit money banks. In view of the above findings it is recommendedthat Nigeria deposit money banks should create more awareness to group users of financial information on the benefits entails to the practice of accounting technology.

\section{REFERENCES}

[1] Agboola A.A (2006); "Electronic payment systems and Tele banking Services in Nigeria"; Journal of Internet Banking and commerce Dec. 2006, Vol. 11 no3 htt://www.arraydev.com/commerce/jibc1).

[2] Akande, O. (2011). Accounting skill as a performance factor for small businesses in Nigeria. Journal of Emerging Trends in Economics and Management Sciences (JETEMS), 2(5), 372-378.

[3] Akesinro and Adetoso, (2016); The effect of computerized accounting system on the performance of banks in Nigeria. Journal of economics and sustainable developments. Vol.7, No.14,2016 
[4] Alam, S., Omar, N., Mohd, N., andHisham, H. (2011). Applying the theory of perceived characteristics of innovating (PCI) on ICT adoption in the SMEs in Malaysia. Australian Journal of Basic and Applied Sciences, 5(8), 8-17.

[5] Al-Helo, Burhan Sabah, 2000, Impact of Using Information Technology and Systems on Integrated Banking Services in Jordanian Banks from the Perspective of Banking Leaderships, unpublished Master thesis, Al Al-Bayt University, Mafraq, Jordan

[6] Ali, A., and Hwang, L.S. (2000). Country-specific factors related to financial reporting and the value relevance of accounting data. Journal of Accounting Research 38(1): 1-21.

[7] Ali, M. J., Ahmed, K., and Henry, D. (2004).” Disclosure compliance with national accounting standards by listed companies in South Asia". Accounting andBusiness Research, 34 (3), pp 183 - 199.

[8] Almbaidin, T. (2014). "The Effectiveness of Accounting Information System in Jordanian Banks: From the Management Perspective" International Bulletin of Business Administration, Issue 14. Awosejo, J., Kekwaletswe, M., Pretorius., P and Zuva, T. (2013). "The Effect of Accounting Information Systems in Accounting”, International Journal of Advanced Computer Research, Vol. 3 No. 3, pp. 142 - 150.

[9] AL-Refaee , K.M (2012), The Effect Of E-Commerce on the Development of the Accounting Information Systems in the Islamic Banks American Journal of Applied Sciences 9 (9): 1479-1490, 2012 ISSN 15469239 (C) 2012 Science Publication.

[10] Alshebeil, A.H (2010) Accounting Information Systems and organization, theory with Study Case Dar Althaqafa library for publishing and distributing, Jordan, 39, 26.

[11] Al-Somali, S., Gholami, R., and Clegg, B. (2011). Determinants of B2B e-commerce adoption in Saudi Arabian firms. International Journal of Digital Society (IJDS), 2(2), 406-415.

[12] Baren, V., (2010), The Importance of a Computerized Accounting System, available on Journal of Applied Management Studies, J(2), 143-158.

[13] Beisland, A.E. (2009). Essays on the Value Relevance of Accounting Information, Working paper of Norwegian school of Economics and Business Administration.

[14] Carol, L. C (2002): How Computers has Simplified Accounting. Retrieved on April, 3, 2011. http://www.yale.edu.

[15] Chang, J. (1998). The Decline in Value Relevance of Earnings and Book Values: Wharton School University of Pennsylvania.

[16] Chavent, M., Ding, Y., Fu, L., Stolowy, H. and Wang, H. (2006). “ Disclosure and determinants studies: An extension using the Divisive Clustering Method (DIV)”. European Accounting Review, 15 (2), pps 181-218.

[17] Chen, F., Hope, O.K., Li, Q And Wong, X. (2010). Financial Reporting Quality AndInvestment Efficiency Of Private Firms. In Emerging Market Accounting Review, Pp 1255-1288.

[18] Cooper, R. B., andZmud, R. W. (1990). Information technology implementation research: A technological diffusion approach. Management Science, 36(2), 123-139.

[19] Copeland, R. M. and Dascher, R. M. (1978). Management Accounting. New York: John Wiley and Sons Incorp.

[20] Davis, F. D., Bagozzi, R. P., andWarshaw, P. R. (1989). User acceptance of computer technology: A comparison of two theoretical models. Management Science, 35(8), 982-1002.

[21] El-Gazzar, S. M., Finn, P.M., andTang, C. (2009). The value relevance of earnings and non earnings information in regulated and deregulated markets: the case of the airline industry. International Advances in Economic Research 15(1):88-101.

[22] Emmanuel Opoku Ware (2015) Computerized Accounting System an Effective Means of KeepingAccounting Records in Ghanaian Banks: a Case Study of the GaRural Bank. International Journal of Research in Business Studies and Management Volume 2, Issue 11, November 2015, PP 111-141ISSN 2394-5923 (Print) and ISSN 2394-5931 (Online).

[23] Irechukwu, G., (2000): ' Enhancing the Performance of Banking Operations Through Appropriate Information Technology, Information Technology in Nigerian Banking Industry, Spectrum Books, Ibadan, pp63-78.

[24] Ironkwe and Otti, 2016; the relationship between Accounting Information and Financial Performance of Banks inNigeria, Journal of Accounting and Financial Management ISSN 2504-8856 Vol. 2 No.3 2016 .www.iiardpub.org

[25] Ismail, N. A., and King, M. (2007). Factors influencing the alignment of accounting information systems in small medium sized Malaysian manufacturing firms. Journal of Information systems and Small Business, 1(1), 1-19. 
[26] Jang-Jaccard, J., and Nepal, S. (2014). A survey or emerging threats in cyber security. Journal of Computer and System Sciences, 80, 973-993.

[27] Khalid, Mohammad Muthar Saleh, 2004, Evaluation of Performance of Computer-Based Accounting Information Systems and their extent of appropriateness to fulfill management needs, unpublished Master thesis, Yarmouk University, Irbid, Jordan.

[28] Mohammadi, A. (2012). The Investigation of Relationship between Accounting Information and the Value of Companies (Case Study), http://www.icndbm.com/pdf/129.pdf.

[29] RaedKanakriyah 2017; the Impact of Accounting Information Systems on the Banks Success: Evidence from Jordan. Research Journal of Finance and Accounting ISSN 2222-1697 (Paper) ISSN 2222-2847 (Online) Vol.8, No.17, 2017

[30] Venkatesh, V., Thong, J. Y., andXu, X. (1996). Consumer acceptance and use of information technology:using unified theory of acceptance and use of technology. Management Information System Quarterly, 36, 157-178.

[31] Vieth S. and Werner J.R (2010). Comparing value relevance across countries: Does the Return window specification matters?

Citation: Oladejo, M.O et al. Implementation of Accounting Technology and Financial Reporting Quality of Quoted Epos it Money Banks in Nigeria " International Journal of Managerial Studies and Research (IJMSR), vol 8, no. 2, 2020, pp. 13-21. doi: http:// dx.doi.org/10.20431/2349-0349.0802002.

Copyright: () 2020 Authors. This is an open-access article distributed under the terms of the Creative Commons Attribution License, which permits unrestricted use, distribution, and reproduction in any medium, provided the original author and source are credited. 